M.D. Johnston, B.A. Muench, E.D. Banks, and H.A. Barton - Human urine in Lechuguilla Cave: the microbiological impact and potential for bioremediation. Journal of Cave and Karst Studies, v. 74, no. 3, p. 278-291. DOI: 10.4311/2011MB0227

\title{
HUMAN URINE IN LECHUGUILLA CAVE: THE MICROBIOLOGICAL IMPACT AND POTENTIAL FOR BIOREMEDIATION
}

\author{
Michael D. Johnston, Brittany A. Muench, Eric D. Banks, and Hazel A. Barton* \\ Department of Biology, University of Akron, Akron, OH 44325
}

\begin{abstract}
During extended exploration trips in caves, it is sometimes not possible to remove all excreted urine due to its volume and weight. Excess urine can be particularly problematic in dry caves where, without dilution, urine introduces a significant source of nitrogen into these otherwise nitrogen-limited environments. It was the aim of this study to determine the impact that human urine could have on cave microbiota over an extended period of time. To do this, we examined the microbial community structure of a heavily impacted site in Lechuguilla Cave, USA. Using a molecular phylogenetic approach we generated a 136-member $16 \mathrm{~S}$ rRNA clone library that demonstrated representatives of the Alpha-Beta- and Gammaproteobacteria, the Bacteroidetes, Firmicutes, Actinobacteria and Deinococcus-Thermus group at this site. The structure of the microbial community at the impacted site suggests that it is colonized by endemic cave species rather than human commensal organisms, while metabolic inference suggests that these organisms are taking advantage of both the nitrogenous and organic compounds in urine for growth. The intrinsic nature of such metabolic activity in the cave environment was confirmed by examining non-impacted sites using cultivation, which demonstrated that endemic species express both the capacity to degrade urine and to reduce urea to nitrogen gas. Our results differ from those of previous studies by implying a more resilient nature of the microbial ecosystem in caves to invasion by exogenous (commensal) species, while suggesting that endemic microbial species may be able to mitigate the impact of excess nitrogen in the cave through bioremediation.
\end{abstract}

\section{INTRODUCTION}

Cave environments become more energy- and nutrientlimited as you travel farther from surface inputs (Barr, 1967; Hardin and Hassell, 1970; Raesly and Gates, 1987; Culver and Sket, 2000; Lavoie et al., 2007), and the environment becomes increasingly difficult for troglobitic species to subsist. As a result, the biome becomes increasingly dominated by microorganisms (Barr, 1967; Culver and Sket, 2000; Barton and Jurado, 2007). Yet in these nutrient-limited environments, even microorganisms are dependent on the availability of both energy and nutrients such as nitrogen, sulfur, and phosphorus for growth. The presence of these nutrients, in both endogenous (autochthonous) and exogenous (allochthonous) form, can have a profound impact on microbial growth and community structure (Ikner et al., 2007; Summers Engel et al., 2010; Iker et al., 2010). Depending on local geochemistry, sulfur and phosphorus may be present within the mineral matrix of the rock; however, there is rarely any intrinsic source of nitrogen in caves (Klimchouk, 2000). As a result, the availability of nitrogen becomes critical for microbial subsistence, as demonstrated by the abundance of nitrogen-fixing bacterial species in cave environments (Northup et al., 2003; Barton et al., 2007; Ikner et al., 2007; Spear et al., 2007). The introduction of allochthonous nitrogen can have a dramatic impact on the microbial community structure in such ecosystems, created by an excess of this normally limited nutrient (Ikner et al., 2007; Iker et al., 2010).

In order to understand caves, humans must enter and explore them (Kambesis, 2007); however, the human exploration of caves has the potential to impact microbial ecosystems through the introduction of nutrients (Northup et al., 1997; Lavoie and Northup, 2005; Ikner et al., 2007). To minimize such impacts, speleologists use a number of techniques, including staying on designated trails, wearing non-marking footwear, avoiding leaving food crumbs, and removing all waste (Northup et al., 1997; Elliott 2006). Some caves are sufficiently large and deep that exploration requires extended periods underground, sometimes exceeding thirty days (Reames et al., 1999; Stone et al., 2002; Tabor, 2010), and the removal of human waste becomes impractical due to weight constraints. If removing all liquid waste is mandated, there is a danger that speleologists will undergo self-induced dehydration to minimize waste and weight. Dehydration, compounded by exercise, can adversely affect judgment and motor skills, increasing the likelihood of an accident (Lieberman, 2007). To avoid the large-scale impact that a rescue would have, it is therefore

*Corresponding Author: bartonh@uakron.edu 
sometimes more reasonable to leave human waste in the cave.

Due to the high protein content of the human diet, excess nitrogen is produced in the form of ammonia $\left(\mathrm{NH}_{3}\right)$ from the catabolism of amino acids (Wright, 1995). This ammonia is excreted as urea $\left[\left(\mathrm{NH}_{2}\right)_{2} \mathrm{CO}\right]$, the major component of urine in mammals. In the environment, microbial hydrolysis can convert this urea back into ammonia (Fig. 1A), which can be assimilated by plants or microorganisms back into amino acids. Ammonia and other nitrogenous species $\left(\mathrm{NO}_{2}^{-}, \mathrm{NO}_{3}^{-}, \mathrm{NO}, \mathrm{N}_{2} \mathrm{O}\right)$ contain nitrogen in a number of valency states, allowing these compounds to function in biological redox reactions (Fig. 1B). Microorganisms, therefore, have the capacity to use ammonia for dissimilatory (energy generating) metabolic processes (Fig. 1A), with the resulting products $\left(\mathrm{NO}_{2}^{-}, \mathrm{NO}_{3}^{-}\right.$, and $\left.\mathrm{N}_{2} \mathrm{O}\right)$ serving in additional (denitrifying) redox reactions (Francis et al., 2007; Fig. 1B). Excess ammonia in a nitrogen-limited environment can impact both microbial nitrogen assimilatory (nitrogen uptake) and dissimilatory (energy generating) processes, with the potential to dramatically change both nitrogen scavenging activities and ecosystem energetics (Iker et al., 2010).

Lechuguilla Cave, New Mexico, is an extensive cave system over $200 \mathrm{~km}$ in length and 500 meters in depth (S. Allison, personal communication, 2010). Exploration of this large system has required extended underground camping trips lasting up to eight days (Reames et al., 1999). Due to the long duration of these trips, urine has been deposited at campsites throughout the cave (Northup et al., 1997; Reames et al., 1999). Because of the potential impact of this urine on microbial-ecosystem dynamics, we examined how microorganisms in Lechuguilla Cave respond to this nutrient at both impacted and nonimpacted sites using a combination of cultivation and molecular phylogenetics. Our results demonstrate a dramatic change in the microbial community in response to urine deposition and suggest the potential for bioremediation strategies to minimize future impacts.

\section{Methods}

\section{Cave Description and Geology}

Lechuguilla Cave is located in Carlsbad Caverns National Park, Eddy County, New Mexico. The cave is located in a desert region and does not connect to any known surface streams, limiting allochthonous nutrient input (Davis, 2000). The cave was formed primarily in the Capitan Formation of the Delaware Basin by hypogenic sulfuric acid speleogenesis with a postulated biogenic origin (Hill, 2000; Palmer and Palmer, 2000; Barton, 2013). Due to the complex geology of the cave, with both back-reef and fore-reef facies, numerous secondary elements can be found within the limestone, including iron, manganese, titanium, silica, and other constituents of sedimentary minerals (Scholle et al., 1992; Northup et al., 2003).
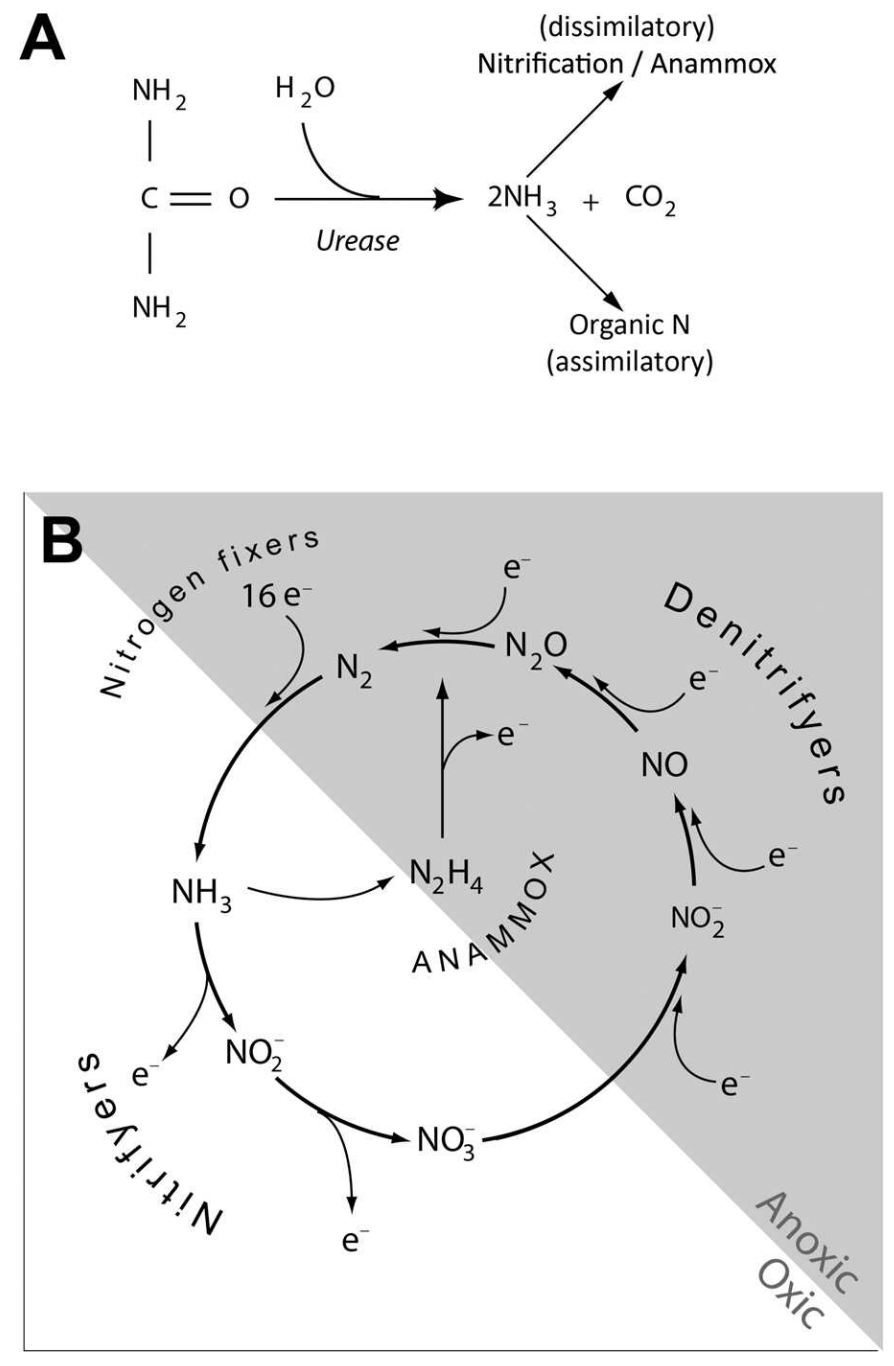

Figure 1. The degradation of urea and the nitrogen cycle. A. A simplification of the breakdown of urea by urease into ammonia. $B$. The nitrogen cycle not only provides nitrogen in a bioavailable form for plants and bacteria $\left(\mathrm{NO}_{3}^{-}\right)$, but the valency of the nitrogen species also allows them to serve as electron donors or electron acceptors in bacterial energygenerating processes. Ammonia is oxidized by nitrifying bacteria into nitrite and nitrate, while nitrate can be reduced by denitrifying bacteria to generate nitrous oxide and nitrogen gas. Under anaerobic conditions, ammonia can be directly oxidized to nitrogen gas by anaerobic ammoniaoxidizing (ANAMMOX) bacteria. In either case, either nitrogen gas from the nitrogen cycle or directly from the air can be made bioavailable by nitrogen-fixing bacteria in the form of ammonia.

\section{Sample Collection and Molecular Techniques}

At the Big Sky campsite, a small depression off the main corridor has served as the urine deposition site for more than twenty years (Fig. 2). The gypsum where the urine was poured has acquired a black patina, similar to that seen at other urine deposit sites within the cave. 


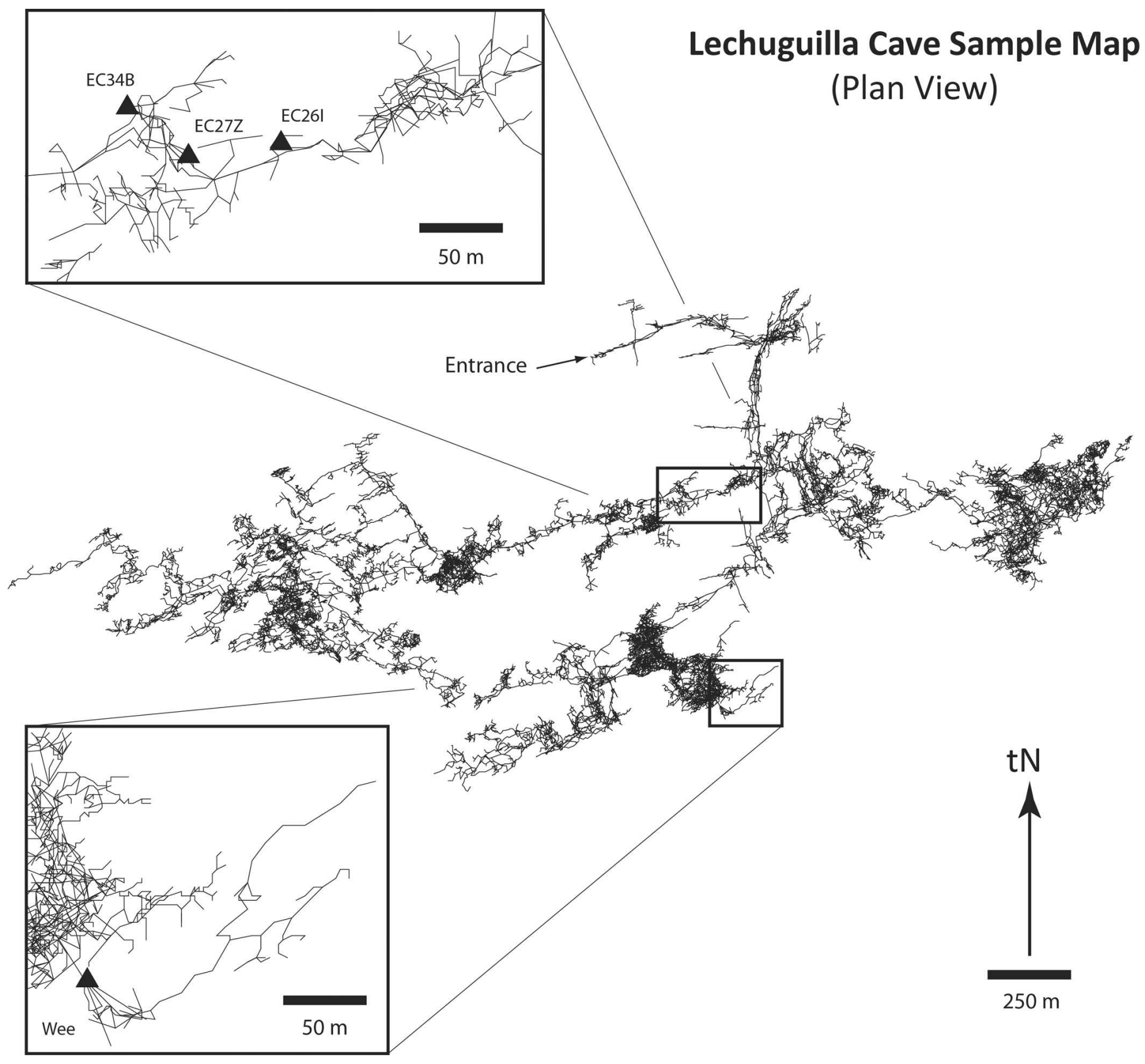

Figure 2. Map of Lechuguilla Cave, showing the relative locations of the sample sites. The sample for molecular phylogenetic analysis was collected at the Big Sky Camp urine site (Wee), while samples collected for cultivation were collected at EC34B, EC27Z, and EC26I in the Western Borehole region.

Approximately one month following the most recent use of this urine site, a $2 \mathrm{~cm}^{3}$ sample of the black patina (designated Wee) was obtained for molecular phylogenetic analysis by breaking off a piece of protruding gypsum using a sterile spatula. A similarly-sized piece of gypsum was collected approximately $40 \mathrm{~m}$ away at a non-impacted site to serve as a control (designated CTL). When collected, the samples were placed in $70 \%$ ethanol for transport out of the cave and stored at $-80{ }^{\circ} \mathrm{C}$ prior to analysis in the lab.
All DNA protocols were carried out in a laminar-flow hood using aerosol-resistant pipette tips to reduce the likelihood of contamination. Negative control isolations were carried out in parallel to measure any contamination of the final samples. DNA was extracted from either $0.5 \mathrm{~mL}$ of liquid culture or $0.5 \mathrm{~g}$ of sediment using our previously described protocol (Barton et al., 2006). Community 16S ribosomal RNA gene sequence libraries for Bacteria were prepared from extracted DNA by amplification using the universal forward primer 8F (5' - AGA GTT TGA TCC 
TGG CTC AG - $3^{\prime}$ ) and bacterial-specific reverse primer 1391R (5' - GAC GGG CGG TGW GTR CA - 3') at an annealing temperature of $58{ }^{\circ} \mathrm{C}$. For an Archaeal library, the archaeal-specific primers $333 \mathrm{Fa}\left(5^{\prime}-\mathrm{TCC}\right.$ AGG CCC TAC GGG - 3') and 1100Ar (5' - TGG GTC TCG CTC GTT $\mathrm{G}-3^{\prime}$ ) were used across a range of annealing temperatures (55 to $65{ }^{\circ} \mathrm{C}$ ) (Hales et al., 1996). Purified PCR products were cloned into a pTOPO-TA Cloning Vector (Invitrogen Corp., Carlsbad, California) according to the manufacturer's recommended protocol. Representative clones were sequenced at the University of Kentucky Advanced Genetic Technologies Center (UK-AGTC; http://www.uky.edu/Centers/AGTC). Partial sequences of each 16S rRNA gene were compiled using DNA Baser Sequence Assembler (Heracle Software Co., Germany) and compared to the NCBI database by BLAST (http://www. ncbi.nlm.nih.gov) (Altschul et al., 1997). The compiled sequences were screened for removal of potential chimeric sequences using Bellerophone software (http://comp-bio. anu.edu.au/bellerophon/bellerophon.pl) (Huber et al., 2004). Remaining sequences were deposited in the NCBI GenBank database (accession numbers JN032353JN032396). DNA alignments were carried out using a NAST aligner (DeSantis et al., 2006) with manual corrections in the ARB Software Package (http://www. arb-home.de), with additional sequences from the Ribosomal Database Project (RDP; Cole et al., 2009) and Rainey et al. (2005). For evolutionary distance calculations, a maximum-likelihood algorithm using a general time-reversal (GTR) substitution model was carried out in RAxML 7.2.7 with 1000 bootstrap replicates to test the robustness of the inferred topologies (Stamatakis et al., 2008). In all cases, Bacillus pumulis was used as the outgroup (AB195283).

\section{Sample Collection for Cultivation And \\ Metabolic Activity}

Samples for cultivation were collected from three pristine locations within Lechuguilla Cave, including two $5 \mathrm{~mL}$ water samples from shallow pool sites (EC26I and EC27Z) and $1 \mathrm{~g}$ of floor sediment (EC34B) collected with sterile syringes and spatulas, respectively (Fig. 2). These samples were used to immediately inoculate $20 \mathrm{~mL}$ of filtersterilized urine (from a healthy $24 \mathrm{yr}$ old male, no medications) under oxic and anoxic conditions in septated vials (Wheaton Scientific, Millville, New Jersey). The anoxic conditions were generated by removing the oxygen from $250 \mathrm{~mL}$ of air using ascorbic acid, with the anaerobic nature of the resultant gas confirmed using an anaerobic test strip. This deoxygenated air was then used to degas each $20 \mathrm{~mL}$ of urine by replacing the headspace gas three times over a twenty-four-hour period. Half of the urine within the vials was treated with $40 \mu \mathrm{L}$ of urease $\left(1 \mathrm{mg} \mathrm{mL}^{-1}\right)$. The result was four culture conditions (urine under oxic and anoxic conditions, and urine plus urease under oxic and anoxic conditions) for each sample site
(Fig. 3). An uninoculated sample was used as a control to verify the sterility of the urine under each condition. All cultures were incubated in the cave $\left(20^{\circ} \mathrm{C}\right)$ for forty-eight hours and transported to the lab at $4{ }^{\circ} \mathrm{C}$ to prevent cell damage from the high temperature variations from shipping during the summer. The primary cultures generated in the cave were sub-cultured two weeks later in the laboratory at $20{ }^{\circ} \mathrm{C}$. Sub-cultures were prepared from $1 \mathrm{~mL}$ samples of the primary cultures, which were used to inoculate $20 \mathrm{~mL}$ of urine media under the described conditions. To determine whether a carbon and energy source was necessary for growth, $40 \mathrm{mg} \mathrm{mL}^{-1}$ of filter-sterilized glucose was included in one set of the sub-cultures, resulting in eight varieties of sub-culture, oxic or anoxic, with or without urease, and with or without glucose (Fig. 3). Three replicate samples from each of the oxic cultures were analyzed for the presence of ammonia, nitrate, and nitrite via spectroscopy with ammonia (TNT 831) and nitrate (TNT 839) test kits (Hach, Loveland, Colorado). Very little variation was observed in the anoxic cultures, and these measurements were not repeated.

For comparative nitrate reduction assays, Pseudomonas strains previously isolated from Lechuguilla Cave (Johnston et al., 2011) were grown in sterile nitrate broth to test for denitrification according to the manufacturer's guidelines (Difco ${ }^{\mathrm{TM}}$ Nitrate Broth, Becton Dickinson, Franklin Lakes, New Jersey) and incubated at room temperature for $48 \mathrm{hrs}$. The presence of gas bubbles was recorded as positive for nitrogenous gas production. Samples were then evaluated for nitrate and nitrite reduction following the manufacturer's recommended protocol.

\section{RESULTS}

To assess the impact of human urine on microorganisms over extended periods in Lechuguilla Cave, we conducted a comparative analysis of the microbialcommunity profile at the Big Sky urine site (Fig. 2). This area of Lechuguilla Cave was discovered in 1989 and has served as a permanent campsite, averaging two to three sixperson expeditions per year. At the end of each expedition, urine is poured into a shallow depression off of the main trail, flowing over rock and gypsum deposits. Over time, this has caused a black patina to develop, as is seen at all the urine sites throughout the cave. The chemistry of this patina is unknown, but the amorphous nature of the residue suggests that it is organic in nature; it closely resembles amberat. A small sample $\left(\sim 2 \mathrm{~cm}^{3}\right)$ of patinacovered gypsum was collected (designated Wee) and examined using molecular phylogenetic techniques to describe the microbial species present following extended exposure to urine. A similar piece of gypsum was collected from an un-impacted area in the general region of the Big Sky site to serve as a negative control (CTL).

We attempted to extract DNA from both the Wee and CTL gypsum samples. While DNA was readily obtained

Journal of Cave and Karst Studies, December 2012 •281 


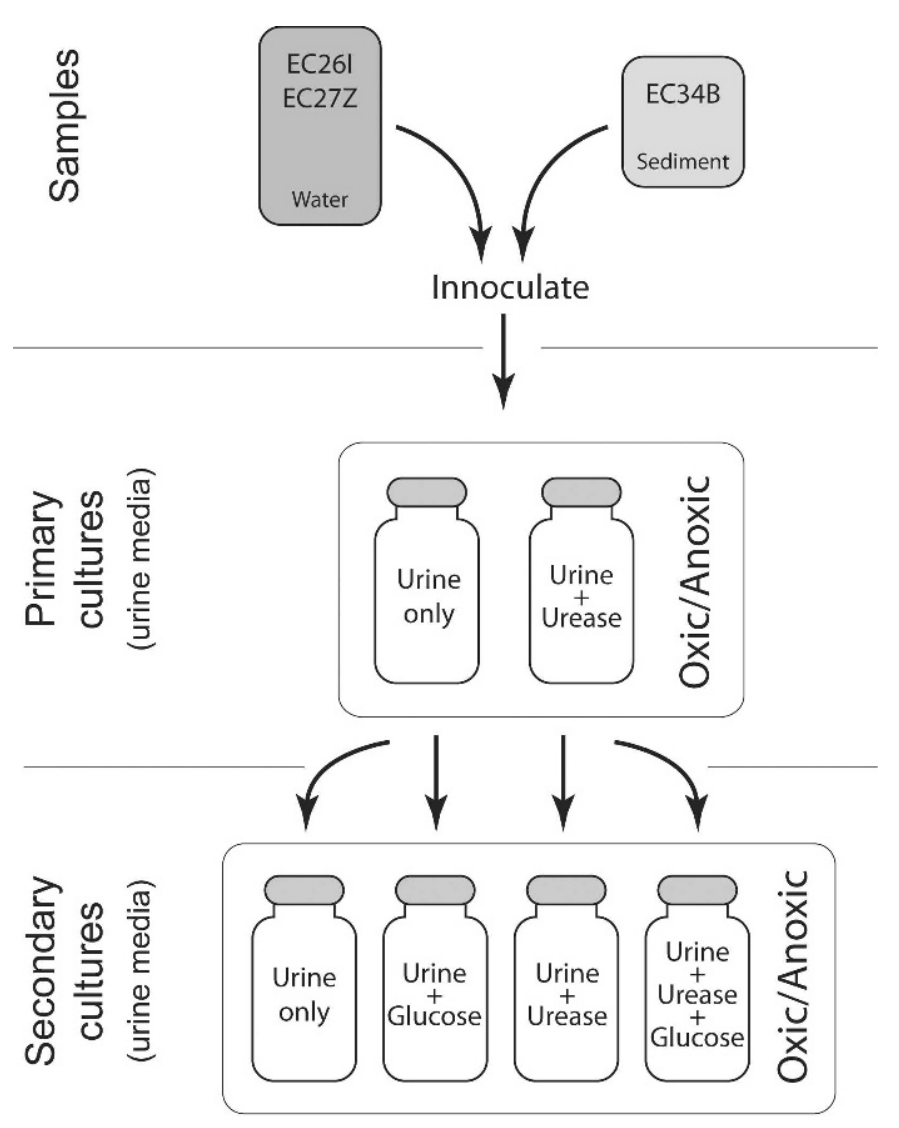

Additives/Conditions

Figure 3. Diagram of described culture conditions. Liquid or sediment samples were inoculated in the cave under four growth conditions to generate the primary cultures: urine under oxic or anoxic conditions, and urine + urease under oxic or anoxic conditions. The secondary cultures were inoculated in the laboratory to create eight growth conditions: urine under oxic or anoxic conditions, urine + glucose under oxic or anoxic conditions, urine + urease under oxic or anoxic conditions, and urine + glucose + urease under oxic or anoxic conditions.

from the Wee samples, three independent attempts were unable to isolate DNA from the CTL sample. This suggests that the total number of microorganisms in the CTL sample was below the detection limit of this assay $\left(\sim 10^{4}\right.$ cells $\mathrm{g}^{-1}$; Barton et al., 2006). A clone library of 136 bacterial phylotypes was generated from the Wee sample DNA via PCR amplification; however, no amplifiable PCR products were obtained using archaeal-specific primers after numerous attempts (data not shown). A comparative BLAST of the bacterial library at the Wee site (Table 1) demonstrated that a significant proportion of the phylotypes $(42 \%)$ had a low level of similarity $(\leq 95 \%)$ to previously identified bacterial species. This low level of identity was unexpected due to the amount of human urine that had been deposited at this site and the presumed presence of human commensal species (Hunter et al., 2004; Lavoie and Northup 2005). A small percentage (9\%) of the 136 phylotypes did have distant similarity to species that have been associated with human populations (WeeA_H02, 92\% identity to a pulmonary infection; WeeA_C08, 97\% identity to a Bacillus isolated from a patient's blood), but the vast majority of the phylotypes identified $(78 \%)$ were related to soil species (Table 1), demonstrating a broad diversity within the Bacteria, including the Alpha-, Beta- and Gammaproteobacteria, the Actinobacteria, Firmicutes, Deinococci-Thermus, and Bacteriodetes. Of interest was the presence of representative phylotypes from the Order Deinococcales, which are not normally associated with cave environments (Cox and Battista, 2005). The Deinococcales identified in the Wee clone library demonstrated a comparatively low $16 \mathrm{~S}$ identity with previously identified representatives of the Deinococci (92 to 95\%) and the cultivated Truepera $(91 \%)$ (Table 1). To determine whether these Deinoccales phylotypes represent a previously undescribed group within this phyla, we generated a phylogenetic tree that included the closest cultured and un-cultured representatives of the Deinococcale from the NCBI and RDP databases (Rainey et al., 2005). Using a maximum likelihood tree-building algorithm, the dendogram suggests that these phylotypes represent a new, previously unrecognized clade within the Deinococci-Thermus (Fig. 4). It is interesting to note that the other representative phylotypes within this clade (HQ727579-81) were found in nitrate- and ammonia-rich environments.

The lack of recognized human commensal species at the Wee site suggested that endemic microbial species, rather than exogenous species, might be subsisting longterm to utilize the urine in situ. To determine if endemic species are capable of utilizing human urine, we attempted to culture bacteria from pristine locations in Lechuguilla Cave using human urine as a culture medium. No carbon or energy sources were added to this urine, allowing us to select for species capable of utilizing organic molecules present in urine as a carbon and energy source (Kusano et al., 2011). The three sample sites, EC26I, EC27Z, and EC34B, were chosen due to their distance from impacted urine sites (Deep Seas, Red Seas, Rusticles, Big Sky, and Far-East camps) and sites of limited human activity (away from major survey junctions or main trails) (Fig. 2). Given that urine is a liquid, pools were sampled at EC26I and EC27Z for planktonic species, while EC34B was a representative sediment sample. The samples were inoculated into $20 \mathrm{~mL}$ of sterile urine (Fig. 3) under oxic $(20 \%$ $\left.\mathrm{O}_{2}\right)$ and anoxic $\left(0 \% \mathrm{O}_{2}\right)$ conditions. Anoxic conditions were included due to the dependence on anaerobic conditions for urease production by a number of bacterial species (Mobley and Hausinger, 1989; McCarty and Bremmer, 1991), while other species can only use ammonia as an energy source under anaerobic conditions (Kowalchuk and Stephen, 2001). Without knowing whether endemic cave species possess the urease activity 


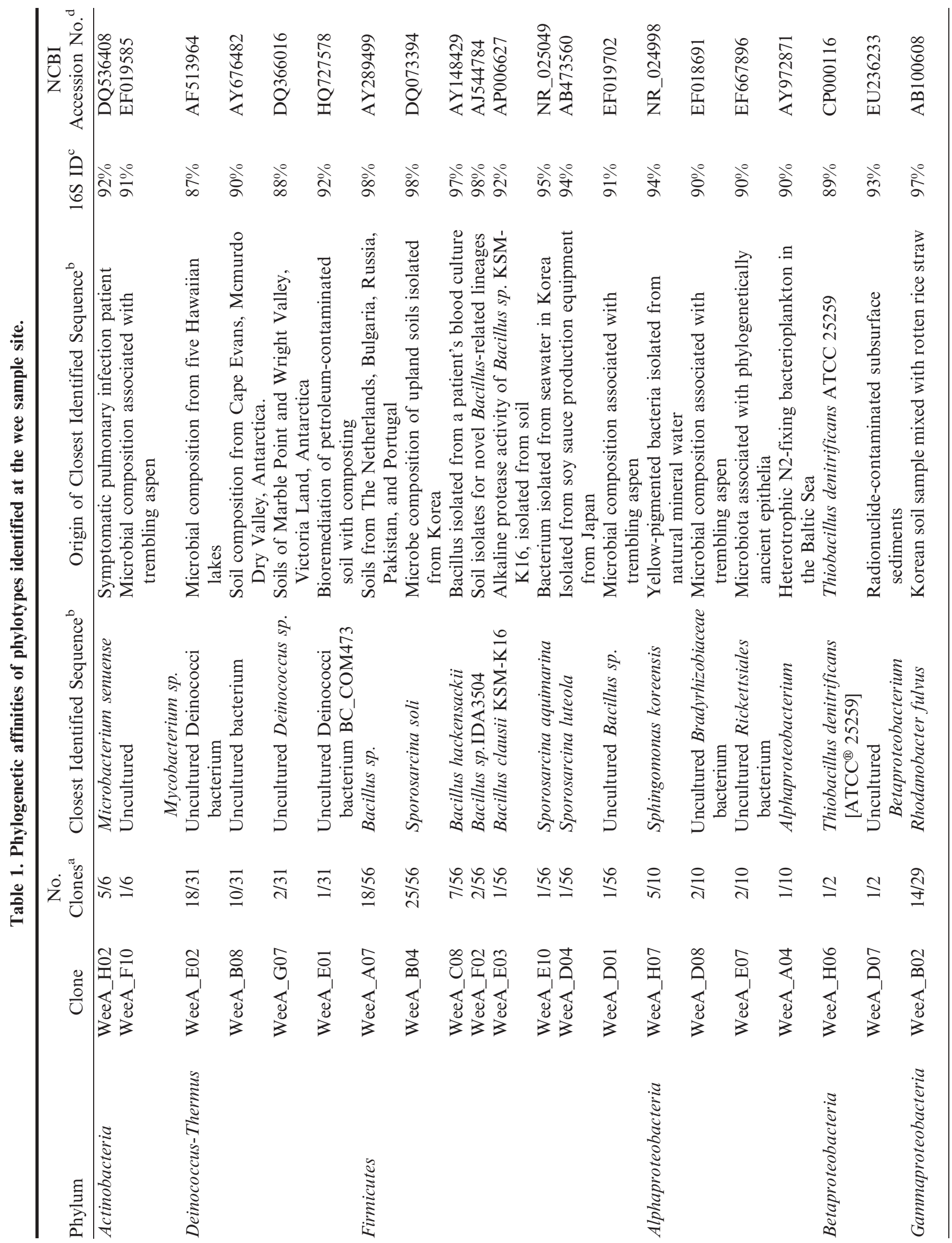




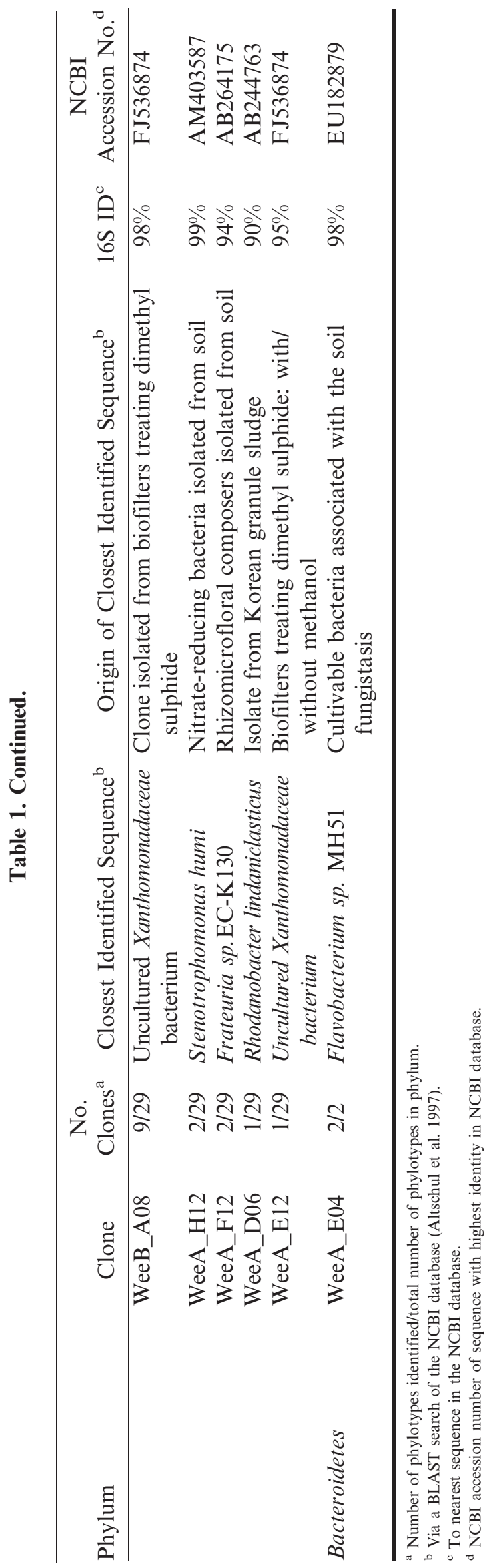

necessary for the first step in urine breakdown, we also included urease pre-treated urine as a medium (Fig. 3).

The cultures were grown at cave temperature $\left(20^{\circ} \mathrm{C}\right)$, and after two weeks significant growth was seen under both oxic and anoxic conditions, with and without the presence of urease. No growth was observed in the uninoculated control. Subcultures of these primary cultures were then established in the laboratory to determine if nitrogen redox-cycling was occurring in terms of nitrifying $\left(\mathrm{NH}_{3}^{+} \rightarrow \mathrm{NO}_{2}^{-}\right)$or denitrifying $\left(\mathrm{NO}_{2}^{-} \rightarrow \mathrm{N}_{2} \mathrm{O} \rightarrow \mathrm{N}_{2}\right)$ activity (Fig. 1B). The one modification to these secondary cultures was the addition of a glucose $\left(40 \mathrm{mg} \mathrm{L}^{-1}\right)$ to determine whether the organic molecules present in urine were sufficient to serve as a carbon and energy source for growth of heterotrophic species, or if additional sources were necessary (Fig. 3).

After five days of growth in the laboratory, the secondary cultures were tested for ammonia, nitrite, and nitrate production. All sterile, uninoculated urine controls were below the level of detection for each of these compounds (data not shown). The data (Fig. 5) demonstrate that ammonia was produced in all cultures regardless of urease addition, although ammonia concentrations were generally higher under anoxic conditions. In all the urine cultures, nitrite was only detected at trace levels $\left(<0.1 \mathrm{mg} \mathrm{L}^{-1}\right.$; data not shown); this low concentration is presumably due to the rapid conversion of nitrite to nitrate by the microbial species present (Roman et al., 1991). The addition of glucose did not appear to significantly increase the production of ammonia or nitrate under the conditions tested. Interestingly, the addition of urease appeared to greatly reduce variability in the amount of ammonia produced in these cultures. This suggests that the variation observed in the EC27Z planktonic culture under aerobic conditions may be due to the production of this enzyme. Nonetheless, the levels of ammonia only had a minimal impact on the resultant nitrate levels in the cultures, and no correlation between ammonia and nitrate concentration was observed.

To account for the comparatively low level of nitrate to ammonia in the samples, we wanted to determine if nitrate was being removed from the culture by reduction to gaseous nitrogen $\left(\mathrm{NO}, \mathrm{N}_{2} \mathrm{O}\right.$, or $\left.\mathrm{N}_{2}\right)$. To test this, we added $1 \mathrm{~mL}$ of each secondary culture (Fig. 3) into $3 \mathrm{~mL}$ of fresh urine media containing a Durham tube. After forty-eight hours of growth, no bubbles were observed in the Durham tubes, suggesting that no gas was produced and hence no nitrate reduction was occurring during growth (data not shown). Nonetheless, it was possible that the absence of gas in these assays was due to limitations in the media used, rather than the absence of nitrate reduction. We therefore inoculated a traditional nitrate broth (Difco) containing Durham tubes from the secondary cultures. Again, no bubbles were observed after forty-eight hours of growth, and testing of the nitrate broth for the presence of nitrite suggested that nitrate reduction was not being carried out in these cultures. 


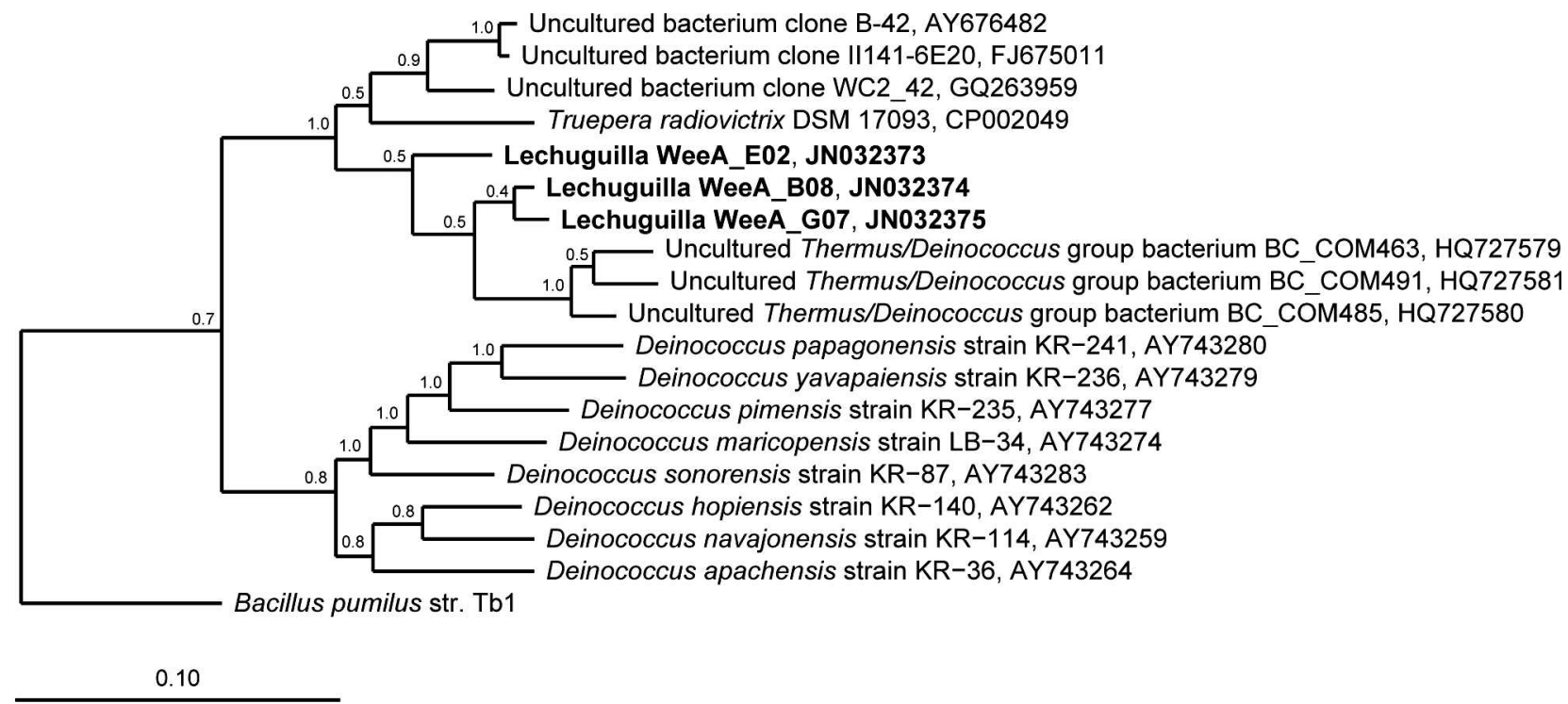

Figure 4. Phylogenetic tree of cultured and uncultured representatives of the Deinococci, demonstrating the unique clade of uncultured Deinococci in which the Wee site phylotypes are found. The dendrogram was constructed using a Maximumlikelihood algorithm. The robustness of the inferred topologies was tested with 1,000 bootstrap replicates, with the likelihood of generating the inferred topology at each node shown. The outgroup used was Bacillus pumulis (AB195283).

Even though complete reduction of ammonia to nitrogen gas was not occurring in the urine cultures, the presence of a trace concentration of nitrite indicates that nitrifying and denitrifying reactions are occurring. To identify the species in these cultures that may be involved in such reactions, we examined the oxic secondary cultures of EC26I, EC27Z and EC34B (without amendment) using a molecular phylogenetic approach. Clone libraries containing twenty-four, twenty-two, and twenty-three bacterial phylotypes were obtained for the EC26I, EC27Z, and EC34B oxic samples, respectively (Table 2). No archaea were identified in these cultures using a PCR-based approach. The pool samples EC26I and EC27Z showed the lowest diversity, while the sediment sample EC34B showed the greatest diversity (Table 2). It is notable that the species identified using this technique demonstrated a high percentage similarity (99 to $100 \%$ ) to previously cultured bacteria, including five with potential similarity to human commensal populations (EC26ID10, EC34BG06, EC34BH08, EC34BE02 and EC34BD06; Table 2), even though all samples came from pristine locations within the cave. One potential explanation of this finding is that filtersterilized, urine was used as a culture medium. It is therefore possible that these genera represented commensal contaminants obtained during urine collection. Nonetheless, our uninoculated controls did not contain microbial growth, and these genera are not known to produce ultrasmall cells capable of passing through a $0.22 \mathrm{~mm}$ filter (Bakken and Olsen, 1987; Rappé et al., 2002; Hahn et al., 2003; Godoy et al., 2005; Miteva and Brenchley, 2005). A number of the identified genera are also known to produce urease or tolerate urea, including representatives of the genera Bacillus, Corynebacteria, Micrococcus, Pseudomonas, and Ochromobactrum (Brenner et al., 2005). Additionally, members of the Bacilli, Corynebacteriaceae, Pseudomonads, and Ochrobactraceae are known to carry out denitrification reactions (Brenner et al., 2005).

Despite the presence of denitrifying species in the cultures, the absence of nitrate reduction to gaseous nitrogen suggests that this final step in the nitrogen cycle is not occurring. In a separate study (Johnston et al., 2011), we have cultured a number of Pseudomonas species from Lechuguilla Cave, a genus that is known to possess this denitrification phenotype (Brenner et al., 2005). To determine if Pseudomonas strains endemic to the cave are capable of complete nitrate reduction (Fig. 1), we carried out a nitrate reduction test on twenty-three Pseudomonas strains, representing five different species (Table 3). Of these isolates, three species, Pseudomonas abientaniphila, Pseudomonas graminis, and Pseudomonas resinovorans, were able to reduce nitrate to nitrite, while Pseudomonas stutzeri was able to completely reduce nitrate to nitrogen gas. This result demonstrates the potential for endogenous cave species to completely oxidize urea to nitrogen gas.

\section{Discussion}

Human exploration allows the systematic documentation of caves and provides a critical component in the scientific understanding of these systems (Kambesis, 2007). Such work has allowed us to build a picture of the geological and hydrological processes that lead to the formation of caves and allowed significant advances in our understanding of speleogenesis, secondary mineral deposi- 

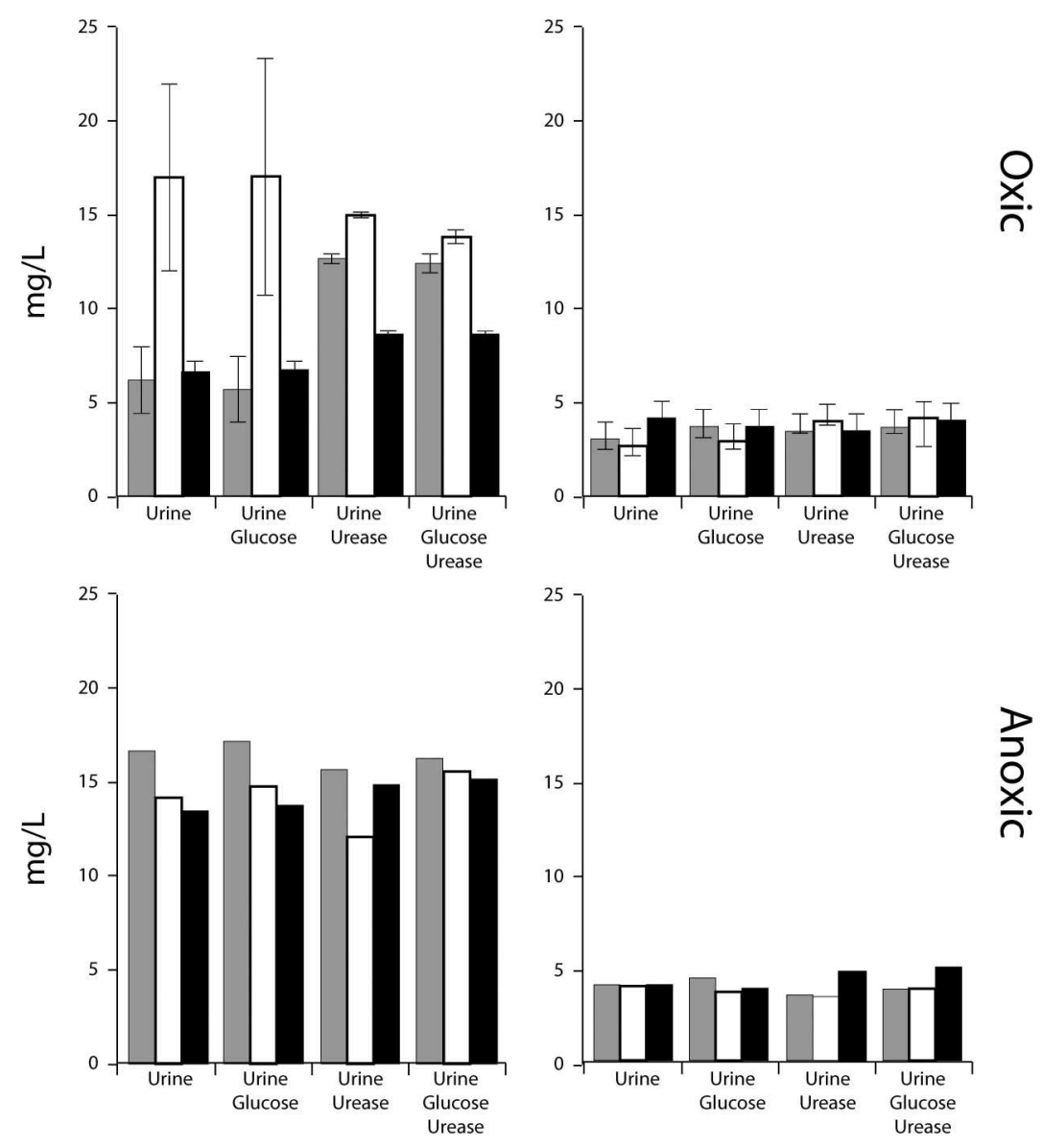

Ammonia

Nitrate

Figure 5. Production of ammonia, nitrite, and nitrate from urine in culture. Bacterial cultures were inoculated from nonimpacted sites in Lechuguilla Cave, EC26I (gray, water), EC27Z (white, water), and EC34B (black, sediment). The average of ammonia and nitrate produced from the breakdown of urea after five days in culture are shown under aerobic and anaerobic conditions. For the oxic cultures, the averages and standard deviations (error bars) of three replicate samples are shown. Nitrite was only detected at trace levels and is not shown.

tion, and cave-ecosystem structure and dynamics. While hydrologically active systems can withstand a higher level of human impact, the consequences of human exploration on environmentally sensitive systems are not known or fully understood (Lavoie, 1995; Lavoie and Northup, 2005). Nonetheless, the limited surface water input into Lechuguilla Cave and the static nature of the environment suggests that this cave may be particularly sensitive to such impacts (Cunningham et al., 1995; Northup et al., 2003).

To examine human impact on the microbial flora of Lechuguilla Cave, Hunter et al. (2004) and Lavoie and Northup (2005) examined the cave system for the presence of bacterial species that could serve as a marker for human contamination. These investigators examined the cave for the presence of fecal (Escherichia coli), skin (Staphylococcus aureus), or soil (Bacilli spp.) bacterial species using chromogenic tests. Hunter et al. (2004) suggested that fecal $E$. coli could be found in pools throughout the cave, while Lavoie and Northup (2005) did not find E. coli in pools, but in pristine sites and active urine dumps. The discrepancy in the findings between studies was attributed by the authors to the short residence time of $E$. coli in cave sediments and its rapid entry into a viable but non-culturable state, making detection difficult using the cultivation-based techniques used in these studies (Lavoie and Northup, 2005). In this study, we use a culture-independent approach that is not subject to the limitations of cultivation (Pace, 1997).

It was our initial aim to carry out a comparative analysis between the endemic microbial population in a geochemically similar, unimpacted site in the cave and the urine-impacted site; however, the unimpacted control did not contain a sufficient microbial population to allow DNA extraction. The extraction techniques used have a detection limit of about $10^{4}$ cells $\mathrm{g}^{-1}$ of sediment, suggesting that the microbial population of the control site contained very few cells, likely due to the osmotic stress of growth on gypsum. The ease of obtaining DNA from the impacted Wee site suggests a much higher biomass at 
Table 2. Identity of cultured bacteria grown on urine media from pristine sites.

\begin{tabular}{|c|c|c|c|c|c|c|}
\hline Sample Site & Clone & No. Clones ${ }^{\mathrm{a}}$ & $\begin{array}{l}\text { Closest Identified } \\
\text { Sequence }^{\mathrm{b}}\end{array}$ & $\begin{array}{l}\text { Origin of Closest } \\
\text { Identified Sequence }^{b}\end{array}$ & $16 \mathrm{~S} \mathrm{ID}^{\mathrm{c}}$ & $\begin{array}{l}\text { NCBI } \\
\text { Accession } \\
\text { No. }^{d}\end{array}$ \\
\hline \multicolumn{7}{|l|}{ EC26I (water) } \\
\hline \multirow[t]{3}{*}{ Actinobacteria } & EC26IB10 & $10 / 22$ & Micrococcus luteus & Medieval wall painting & $99 \%$ & AJ409096 \\
\hline & EC26IB04 & $7 / 22$ & Micrococcus sp.JL-76 & Marine environment & $99 \%$ & AY745846 \\
\hline & EC26ID10 & $5 / 22$ & $\begin{array}{l}\text { Cellulomonas } \\
\text { parahominis }\end{array}$ & $\begin{array}{l}\text { Clinical isolates of } \\
\text { Coryneform group }\end{array}$ & $99 \%$ & AY655729 \\
\hline Firmicutes & EC26IA02 & $2 / 2$ & Paenibacillus borealis & $\begin{array}{l}\text { Humus bacteria of } \\
\text { Norway spruce }\end{array}$ & $90 \%$ & NR_025299 \\
\hline \multicolumn{7}{|l|}{ EC27A (water) } \\
\hline Firmicutes & EC27ZB01 & $12 / 12$ & $\begin{array}{l}\text { Bacillus pumilus } \\
\text { SAFR-032 }\end{array}$ & $\begin{array}{l}\text { Soil polluted with } \\
\text { chromium }\end{array}$ & $99 \%$ & DQ416781 \\
\hline Alphaproteobacteria & EC27ZA05 & $10 / 10$ & $\begin{array}{l}\text { Ochrobactrum } s p \text {. } \\
\text { TK14 }\end{array}$ & $\begin{array}{l}\text { Soil and wheat roots } \\
\text { samples }\end{array}$ & $99 \%$ & AJ550273 \\
\hline \multicolumn{7}{|l|}{ EC34B (sediment) } \\
\hline \multirow[t]{3}{*}{ Actinobacteria } & EC34BG06 & $1 / 3$ & $\begin{array}{l}\text { Corynebacterium } \\
\text { jeikeium K411 }\end{array}$ & Nosocomial pathogen & $99 \%$ & CR931997 \\
\hline & ЕC34BH03 & $1 / 3$ & $\begin{array}{l}\text { Rhodococcus } \\
\text { erythropolis }\end{array}$ & $\begin{array}{l}\text { Rocks of an ancient } \\
\text { gold mine }\end{array}$ & $99 \%$ & EF491951 \\
\hline & ЕC34BH08 & $1 / 3$ & $\begin{array}{c}\text { Propionibacterium } \\
\text { acnes JCM6473 }\end{array}$ & $\begin{array}{l}\text { 16S rRNA gene sequence } \\
\text { of JCM strain }\end{array}$ & $100 \%$ & AB573714 \\
\hline \multirow[t]{2}{*}{ Firmicutes } & EC34BB05 & $4 / 5$ & $\begin{array}{l}\text { Uncultured } \\
\text { bacterium KSC2-41 }\end{array}$ & Spacecraft clean room & $99 \%$ & DQ532287 \\
\hline & EC34BE10 & $1 / 5$ & $\begin{array}{l}\text { Bacillus } \\
\text { weihenstephanensis } \\
\text { KBAB4 }\end{array}$ & $\begin{array}{l}\text { Root-associated } \\
\text { bacteria }\end{array}$ & $99 \%$ & CP000903 \\
\hline Alphaproteobacteria & EC34BA04 & $5 / 5$ & $\begin{array}{l}\text { Bradyrhizobium } \\
\quad \text { elkanii }\end{array}$ & $\begin{array}{l}\text { Commercial rhizobial } \\
\text { strains }\end{array}$ & $99 \%$ & FJ025139 \\
\hline Betaproteobacteria & EC34BC01 & $2 / 2$ & Ralstonia sp. Cl & $\begin{array}{l}\text { Biofilm in spent nuclear } \\
\text { fuel pool }\end{array}$ & $99 \%$ & AY479983 \\
\hline \multirow[t]{4}{*}{ Gammaproteobacteria } & EC34BD05 & $2 / 6$ & Acinetobacter sp. & Bovine products and soil & $99 \%$ & Z93442 \\
\hline & EC34BE02 & $2 / 6$ & $\begin{array}{l}\text { Clone nbt97q09 } \\
\text { (Pseudomonas) }\end{array}$ & Human skin microbiota & $99 \%$ & EU539061 \\
\hline & EC34BA02 & $1 / 6$ & $\begin{array}{l}\text { Pseudomonas } \\
\text { fluorescens } \mathrm{Pf0}-1\end{array}$ & $\begin{array}{l}\text { Corn plant, greenhouse } \\
\text { conditions }\end{array}$ & $99 \%$ & AY958233 \\
\hline & EC34BG09 & $1 / 6$ & Serratia proteamaculans & $\begin{array}{l}\text { Lau Basin hydrothermal } \\
\text { vents }\end{array}$ & $99 \%$ & CP000826 \\
\hline Bacteroidetes & EC34BD06 & $2 / 2$ & $\begin{array}{l}\text { Uncultured bacterium } \\
\text { rRNA082 }\end{array}$ & $\begin{array}{l}\text { Human vaginal } \\
\text { epithelium }\end{array}$ & $99 \%$ & AY958855 \\
\hline
\end{tabular}

this location, which corresponds to the findings of Lavoie (1995), who demonstrated that urine amendment of sediments from Lechuguilla Cave led to a dramatic increase in cell number, from less than $10^{4}$ to $10^{7}$ cells $\mathrm{g}^{-1}$. This suggests that the urine deposition at the Wee site led to a dramatic increase in population size. This increase in numbers also matches the detection limits of our assay (Barton et al., 2006; Lavoie, 1995).
Using a molecular phylogenetic analysis of this increased population at the Big Sky urine site, we found twelve phylotypes that demonstrated some similarity to human isolates, including similarity to a bacterium from human pulmonary (WeeA_H02) and blood (WeeA_C08) infections, but these phylotypes show only a weak similarity (92 and 97\%, respectively) to these pathogens. Such low $16 \mathrm{~S}$ similarity suggests that these phylotypes do 
Table 3. Nitrogen reduction in Lechuguilla Cave Pseudomonad cultures.

\begin{tabular}{lcccccc}
\hline Strains & & & & \multicolumn{3}{c}{ Metabolic Test } \\
\hline Bacteria & $\% \mathrm{ID}^{\mathrm{a}}$ & $\mathrm{No}{ }^{\mathrm{b}}$ & & $\mathrm{N}_{2}$ & $\mathrm{NO}_{2}{ }^{-}$ & $\mathrm{NO}_{3}{ }^{-}$ \\
\hline Pseudomonas stutzeri & 99 & 16 & & + & - & + \\
Pseudomonas abietaniphila & 99 & 1 & & - & + & $\mathrm{ND}^{\mathrm{c}}$ \\
Pseudomonas graminis & 98 & 1 & & - & + & $\mathrm{ND}^{\mathrm{c}}$ \\
Pseudomonas resinovorans & 99 & 2 & & - & + & $\mathrm{ND}^{\mathrm{c}}$ \\
Pseudomonas gingeri & 99 & 3 & & - & - & - \\
\hline
\end{tabular}

${ }^{\text {a }}$ To type strain (P. stutzeri ATCC 17587, P. abietaniphila ATCC 700689, P. graminis ATCC 700544, P. resinovorans ATCC 14235, P. gingeri NCPPB 3146).

${ }^{\mathrm{b}}$ The total number of strains in the Lechuguilla Culture Collection.

${ }^{\mathrm{c}} \mathrm{ND}=$ not done (nitrate positive tests can not be tested for nitrate reduction using this assay).

not belong to the same species (or in the case of $92 \%$ identity, the same genera) as these potential human pathogens (Gevers et al., 2005). Further, these phylotypes are also members of genera commonly found in cave environments (Microbacterium and Bacillus; Johnston et al., 2011), supporting an endemic origin for these species. In this study, we did not find $E$. coli in our Wee sample site or cultures using the more sensitive and specific molecular approach. The cultivation-based chromogenic techniques of Hunter et al. (2004) and Lavoie and Northup (2005) measure a single phenotypic characteristic to identify E. coli, in this case lactose fermentation. Yet a number of the cultured species identified in this study also ferment lactose, including members of the Cellulomonaceae, Micrococci, Paenibacilli, and Bacilli (Tables 1 and 2). Thus, the identification of bacteria based exclusively on lactose fermentation would give a false-positive for fecal coliforms. As such, the presence of $E$. coli within the cave requires supporting evidence (Barton and Pace, 2005). Such evidence could come in the form of confirmatory tests, including culture (mTEC), morphological (Gram stain), and molecular (16S ribotyping) assays (Barton and Pace, 2005), but no such confirmatory tests were carried out in these previous studies (Hunter et al., 2004; Lavoie and Northup, 2005).

Our phylogenetic analysis does not demonstrate the presence of $E$. coli or other fecal bacterial species at the sample site. This does not indicate that they are not being deposited, but that the commensals may not be able to compete or subsist under the conditions of the cave. The loss of commensal species from an environment contaminated by human waste (German toilets) has previously been described (Egert et al., 2010). There the source of the endemic species was determined to be from the environment (from flushing) and this may be the case here; the environmental source is the cave itself.

The presence of a number of phylotypes potentially involved in nitrogen-cycling activities at the Wee site (specifically denitrification; Table 1) suggests that the bacterial species at the urine site may be taking advantage of nitrogenous compounds derived from the urine for energy generation. The presence of numerous phylotypes with similarity to heterotrophic soil species also suggests that the species present could be taking advantage of the organic compounds found in urine for growth (Kusano et al., 2011). The identification of members of the Deinococcales group is much harder to reconcile at this location. The Deinococci-Thermus group represent a heterotrophic, deeply branching lineage within the Bacteria (Alburquerque et al., 2005; Dworkin et al., 2006) that are known for their high level of resistance to ionizing (X-, $\alpha-$, $\beta$ - and $\gamma$-rays) and non-ionizing (UV) radiation (Cox and Battista, 2005). It is unlikely that Lechuguilla Cave provides selective pressure from radiation, particularly from UV radiation, but the mechanisms of DNA repair that provide radiation resistance for these species also allow resistance to dehydration (Mattimore and Battista, 1996). Truepera radiovictrix, which shows closer homology to the phylotypes in our phylogenetic analysis than other cultured members of the Deinococci, has been shown to use nitrate as an electron acceptor (Alburquerque et al., 2005). This suggests that nitrate within the environment may be providing an additional selection pressure. It is interesting to note that the Deinococcales are readily cultured on heterotrophic media, such as that used in previous studies (Hunter et al., 2004; Lavoie and Northup, 2005), and display lactose fermentation capabilities (Rainey et al., 2005; Alburquerque et al., 2005).

Our phylogenetic results suggested that the breaking down of human urine at the Wee site may be being facilitated by endemic cave species. To test whether endemic species demonstrate this capacity, we established cultures from cave sites that had not been impacted by human urine (Fig. 2). Even though these cultures were established with microorganisms from pristine sites, the bacteria identified had similar $16 \mathrm{~S}$ rDNA identity to human commensal species, including members of the Cellulomonas, Corynebacterium, Propionibacterium, and Pseudomonas genera (EC26ID10, EC34BG06, EC34BH08, EC34BE02, and EC34BD06). Rather than being indicative of contamination at these sites, it is likely that the urine in our culture medium enriches for the growth of bacterial species able to utilize urea, resist the high levels of urea encountered, or catabolize the organic molecules found 
in the urine (Kusano et al., 2011). Indeed, the genera represented by these isolates have been associated with human urinary-tract infections, increasing the likelihood of their cultivation using this approach (Sellin et al., 1975; Carpenter and Dicks, 1982; Mobley and Hausinger, 1989; Kunin, 1994; Kesserü et al., 2002; Walter et al., 2007; Zhao et al., 2010). Similar phylotypes have also been found in other caves and subsurface environments, including gold mines and the soil (Table 2), suggesting that the origin of these species was the cave environment.

Given an endemic origin of the species found associated with urine in this study, it is interesting to note that among the samples from pristine sites, the water samples EC26I and EC27Z showed the lowest species diversity (four and two phylotypes, respectively), while the sediment sample EC34D demonstrated the highest (thirteen phylotypes in six divisions). The EC26I culture is dominated by heterotrophic species (Table 2), including members of the Micrococci, Cellulomonaceae, and Paenibacilli. While Micrococci are potential human commensals, we have previously isolated members of this genus within caves (Johnston et al., 2011). Indeed, the isolate cultured in this study (EC26IB10) shared the highest identity to a bacterium isolated from the wallpainting of a medieval church (Table 2), arguing for an organism better adapted to nutrient limitation than human skin (Wieser et al., 2002). The pool culture EC27Z contained near-equal phylotypes of Bacillus pumilus and a representative of the Ochrobactrum (Table 2). Both have previously been isolated from cave environments (Johnston et al., 2011) and are capable of heterotrophic nitrification and aerobic denitrification (Zhao et al., 2010). The urine culture from the sediment (EC34B) sample contained the greatest diversity of heterotrophic species and reflects a more complex ecosystem involved in nitrogen cycling, including representatives of the Rhodococci, Bradyrhizobia, and Ralstonia (Dworkin et al., 2006). Members of the Cellulomonas, Micrococci, and Paenibacilli are also lactose-fermenting species, suggesting that cultivation from pristine sites can also generate false positives for the presence of E. coli (Hunter et al., 2004; Lavoie and Northup, 2005).

In all the established cultures, the microorganisms present seem capable of breaking down urine without the addition of an exogenous carbon source or urease. Under anaerobic conditions, the conversion of urea to ammonia via urease appeared to occur at high levels (Fig. 5), an observation consistent with the increased urease activity of soil species under anaerobic conditions (McCarty and Bremmer, 1991). Although none of our established cultures demonstrated the complete reduction of urea to $\mathrm{N}_{2}$, Pseudomonas species previously isolated from Lechuguilla Cave were able to reduce accumulated $\mathrm{NO}_{3}^{-}$to $\mathrm{N}_{2}$. Collectively, this suggests that it might be possible to engineer a collection of endemic cave species that could completely oxidize urea to $\mathrm{N}_{2}$ gas, without supplementation with additional nutrients (an energy source or urease). These species could then to be added to the urine before it is dumped in the cave. By reducing the total amount of nitrogen in the urine, it might be possible to limit the introduction of nitrogen compounds in urine using an ecosystem-neutral method of in situ bioremediation.

Our data demonstrate that even under the pressure of allochthonous nitrogen and exogenous bacterial species, the microbial community at the Big Sky urine site still appears to be dominated by indigenous cave species. The data suggest that the native microbial community remains resistant to invasion from human commensal species. Factors that could make the microbial ecosystem resistant to such xenobiotic invasion may be the uniquely oligotrophic nature of the cave environment that limits the establishment of copiotrophic species (Barton and Jurado, 2007), the impact of host-rock geochemistry on growth (Barton et al., 2007), or even the selection pressure of the gypsum present at this site. High species diversity can also play a role in community resistance to environmental perturbations, allowing metabolic flexibility and community adaptation under ever-changing conditions (Girvan et al., 2005). To determine what factors control the diversity and speciation of the microbial community at the Wee and other urine sites will require additional experiments, including additional cultivation and in-depth biogeochemistry of the urine sites within Lechuguilla Cave.

The dramatic change in the structure of the microbial community at the Wee site supports the established caving principles: it is important to limit human impact in cave environments, particularly from the introduction of waste. While the microbial community at the Wee site remains dominated by endemic species, it is clearly different from a nearby un-impacted site in the cave (CTL). Without knowing the long-term impact of such a dramatic change on the entire microbial ecosystem, such impacts must be limited by employing sound management practices to balance the delicate nature of the ecosystem with our need to understand and protect these critical habitats.

\section{ACKNOWLEDGEMENTS}

The authors would like to thank Bradley Lubbers, David Bunnell, and Elizabeth Rosseau for assistance with sample collection, three anonymous reviewers for comments that improved the manuscript, and Dr. Kathleen Lavoie for critical comments and valuable references. The authors would also like to thank Paul Burger and Stan Allison of Carlsbad Caverns National Park for access and in-cave assistance. Funding was provided by the NSF KY EPSCoR Program to HAB.

\section{REFERENCES}

Albuquerque, L., Simões, C., Fernando Nobre, M., Pino, M.N., Battista, J.R., Silva, M.T., Rainey, F.A., and da Costa, M.S., 2005, Truepera radiovictrix gen. nov., sp. nov., a new radiation resistant species and the proposal of Trueperaceae fam. nov.: FEMS Microbiology Letters, v. 247, p. 161-169. doi:10.1016/j.femsle.2005.05.003.

Journal of Cave and Karst Studies, December 2012 •289 
Altschul, S.F., Madden, T.L., Schäffer, A.A., Zhang, J., Zhang, Z., Miller, W., and Lipman, D.J., 1997, Gapped BLAST and PSI-BLAST: a new generation of protein database search programs: Nucleic Acids Research, v. 25, p. 3389-3402. doi:10.1093/nar/25.17.3389.

Bakken, L., and Olsen, R., 1987, The relationship between cell size and viability of soil bacteria: Microbial Ecology, v. 13, p. 103-114. doi:10.1007/BF02011247.

Barr, T.C. Jr., 1967, Observations on the ecology of caves: American Naturalist, v. 101, p. 475-491.

Barton, H.A., 2013, Biospeleogenesis: Biogenetic Processes and Microbial Impact on Speleogenesis, Frumkin, A., ed., Treatise on Geomorphology: Atlanta, GA, Elsevier, (in press).

Barton, H.A., and Jurado, V., 2007, What's up down there? Microbial diversity in caves: Microbe, v. 2, p. 132-138.

Barton, H.A., and Pace, N.R., 2005, Discussion: Persistent coliform contamination in Lechuguilla Cave pools: Journal of Cave and Karst Studies, v. 67 , p. $55-57$.

Barton, H.A., Taylor, N.M., Kreate, M.P., Springer, A.C., Oehrle, S.A., and Bertog, J.L., 2007, The impact of host rock geochemisry on bacterial community structure in oligotrophic cave environments: International Journal of Speleology, v. 36, p. 93-104.

Barton, H.A., Taylor, N.M., Lubbers, B.R., and Pemberton, A.C., 2006, DNA extraction from low-biomass carbonate rock: an improved method with reduced contamination and the low-biomass contaminant database: Journal of Microbiology Methods, v. 66, p. 21-31. doi.org/10.1016/j.mimet.2005.10.005.

Brenner, D.J., Krieg, N.R., and Staley, J.T., 2005, eds., Bergey's Manual of Systematic Bacteriology, Volume 2: The Proteobacteria, Part C: The Alpha-, Beta-, Delta- and Gammaproteobacteria, second edition: New York, Springer, 1392 p.

Carpenter, E.M., and Dicks, D., 1982, Isolation of Pseudomonas fluorescens after suprapubic catheterisation: Journal of Clinical Pathology, v. 35, 581 p.

Cole, J.R., Wang, Q., Cardenas, E., Fish, J., Chai, B., Farris, R.J., KulamSyed-Mohideen, A.S., McGarrlll, D.M., Marsh, T., Garrity, G.M., and Tiedje, J.M., 2009, The Ribosomal Database Project: improved alignments and new tools for rRNA analysis: Nucleic Acids Research, v. 37, supplement 1, p. D141-145. doi:10.1093/nar/gkn879.

Cox, M.M., and Battista, J.R., 2005, Deinococcus radiodurans - The consummate survivor: Nature Reviews Microbiology, v. 3, p. 882 892. doi:10.1038/nrmicro1264.

Culver, D.C., and Sket, B., 2000, Hotspots of subterranean biodiversity in caves and wells: Journal of Cave and Karst Studies, v. 62, p. 11-17.

Cunningham, K.I., Northup, D.E., Pollastro, R.M., Wright, W.G., and LaRock, E.J., 1995, Bacteria, fungi and biokarst in Lechuguilla Cave, Carlsbad Caverns National Park, New Mexico: Environmental Geology, v. 25, p. 2-8. doi:10.1007/BF01061824.

Davis, D.G., 2000, Extraordinary features of Lechuguilla Cave, Guadalupe Mountains, New Mexico: Journal of Cave and Karst Studies, v. 62 , p. $147-157$

DeSantis, T.Z. Jr., Hugenholtz, P., Keller, K., Brodie, E.L., Larsen, N., Piceno, Y.M., Phan, R., and Andersen, G.L., 2006, NAST: a multiple sequence alignment server for comparative analysis of 16S rRNA genes: Nucleic Acids Reseach, v. 34, supplement 2, p. W394-399. doi:10.1093/nar/gkl244.

Dworkin, M., Falkow, S., Rosenberg, E., Schleifer, K.H., and Stackebrandt, E., 2006, The Prokaryotes: A Handbook of the Biology of Bacteria, third edition: New York, Springer, 7 volumes.

Egert, M., Schmidt, I., Bussey, K., and Breves, R., 2010, A glimpse under the rim - the composition of microbial biofilm communities in domestic toilets: Journal of Applied Microbiology, v. 108, p. 1167 1174. doi:10.1111/j.1365-2672.2009.04510.x.

Elliott, W.R., 2006, Biological dos and don'ts for cave conservation and restoration, in Hildreth-Werker, V., and Werker, J.C., eds., Cave Conservation and Restoration: Huntsville, National Speleological Society, p. 33-46.

Francis, C.A., Beman, M.J., and Kuypers, M.M.M., 2007, New processes and players in the nitrogen cycle: The microbial ecology of anaerobic and archaeal ammonia oxidation: The ISME Journal, v. 1, p. 19-27. doi:10.1038/ismej.2007.8.

Gevers, D., Cohan, F.M., Lawrence, J.G., Spratt, B.G., Coenye, T., Feil, E.J., Stackebrandt, E., Van de Peer, Y., Vandamme, P., Thompson, F.L., and Swings, J., 2005, Re-evaluating prokaryotic species: Nature Reviews Microbiology, v. 3, p. 733-739. doi:10.1038/nrmicro1236.
Girvan, M.S., Campbell, C.D., Killham, K., Prosser, J.I., and Glover, L.A., 2005, Bacterial diversity promotes community stability and functional resilience after perturbation: Environmental Microbiology, v. 7, p. 301-313. doi:10.1111/j.1462-2920.2005.00695.x.

Godoy, F., Vancanneyt, M., Martínez, M., Steinbüchel, A., Swings, J., and Rehm, B.H., 2003, Sphingopyxis chilensis sp. nov., a chlorophenol-degrading bacterium that accumulates polyhydroxyalkanoate, and transfer of Sphingomonas alaskensis to Sphingopyxis alaskensis comb. nov.: International Journal of Systematic and Evolutionary Microbiology, v. 53, p. 473-477.

Hahn, M.W., Lunsdorf, H., Wu, Q., Schauer, M., and Hofle, M.G., 2003, Isolation of novel ultramicrobacteria classified as Actinobacteria from five freshwater habitats in Europe and Asia: Applied and Environmental Microbiology, v. 69, p. 1442-1451. doi:10.1128/AEM.69.3. 1442-1451.2003.

Hales, B.A., Edwards, C., Ritchie, D.A., Hall, G., Pickup, R.W., and Saunders, J.R., 1996, Isolation and identification of methanogenspecific DNA from blanket bog peat by PCR amplification and sequence analysis: Applied and Environmental Microbiology, v. 62, p. $668-675$.

Hardin, J.W., and Hassell, M.D., 1970, Observation on waking periods and movements of Myotis sodalis during hibernation: Journal of Mammalogy, v. 51, p. 829-831.

Hill, C.A., 2000, Sulfuric acid, hypogene karst in the Guadalupe Mountains of New Mexico and West Texas (U.S.A.), in Klimchouk, A.B., Ford, D.C., Palmer, A.N., and Dreybrodt, W., eds., Speleogenesis: Evolution of Karst Aquifers: Huntsville, National Speleological Society, p. 309-316.

Huber, T., Faulkner, G., and Hugenholtz, P., 2004, Bellerophon; a program to detect chimeric sequences in multiple sequence alignments: Bioinformatics, v. 20 , p. 2317-2319. doi:10.1093/bioinformatics/ bth226.

Hunter, A.J., Northup, D.E., Dahm, C.N., and Boston, P.J., 2004, Persistent coliform contamination in Lechuguilla cave pools: Journal of Cave and Karst Studies, v. 66, p. 102-110.

Iker, B.C., Kambesis, P., Oehrle, S.A., Groves, C., and Barton, H.A., 2010, Microbial atrazine breakdown in a karst groundwater system and its effect on ecosystem energetics: Journal of Environmental Quality, v. 39, p. 509-518. doi:10.2134/jeq2009.0048.

Ikner, L.A., Toomey, R.S., Nolan, G., Neilson, J.W., Pryor, B.M., and Maier, R.M., 2007, Culturable microbial diversity and the impact of tourism in Kartchner Caverns, Arizona: Microbial Ecology, v. 53, p. 30-42. doi:10.1007/s00248-006-9135-8.

Johnston, M., Millette, J., Banks, E.D., Jurado, V., and Barton, H.A., 2011, The culturable diversity of oligotrophic heterotrophs: The lechuguilla cave culture library, in Proceedings of the American Society for Microbiology General Meeting. New Orleans, LA: Washington, D.C., American Society for Microbiology, N1795 p.

Kambesis, P., 2007, The importance of cave exploration to scientific research: Journal of Cave and Karst Studies, v. 69, p. 46-58.

Kesserü, P., Kiss, I., Bihari, Z., and Polyák, B., 2002, The effects of $\mathrm{NaCl}$ and some heavy metals on the denitrification activity of Ochrobactrum anthropi: Journal of Basic Microbiology, v. 42, p. 268-276. doi:10.1002/ 1521-4028(200208)42:4<268::AID-JOBM268>3.0.CO;2-E.

Klimchouk, A.B., Ford, D.C., Palmer, A.N., and Dreybrodt, W., eds., 2000, Speleogenesis, Evolution of Karst Aquifers: Huntsville, National Speleological Society, $527 \mathrm{p}$.

Kowalchuk, G.A., and Stephen, J.R., 2001, Ammonia-oxidizing bacteria: A model for molecular microbial ecology: Annual Review of Microbiology, v. 55, p. 485-529. doi:10.1146/annurev.micro.55. 1.485 .

Kunin, C.M., 1994, Urinary tract infections in females: Clinical Infectious Diseases, v. 18, p. 1-12. doi:doi:10.1093/clinids/18.1.1.

Kusano, M., Mendez, E., and Furton, K.G., 2011, Development of headspace SPME method for analysis of volatile organic compounds present in human biological specimens: Analytical and Bioanalytical Chemistry, v. 400, p. 1817-1826. doi:10.1007/s00216-011-4950-2.

Lavoie, K.H., 1995, The effects of urine deposition on microbes in cave soils, in Proceedings of the 1993 National Cave Management Symposium Proceedings, Carlsbad, NM,: Huntsville, AL, National Speleological Society, p. 302-312.

Lavoie, K.H., Helf, K.L., and Poulson, T.L., 2007, The biology and ecology of North American cave crickets: Journal of Cave and Karst Studies, v. 69, p. 114-134. 
Lavoie, K.H., and Northup, D.E., 2005, Bacteria as indicators of human impact in caves, in Rea, G.T., ed., Proceedings of the 17th National Cave and Karst Management Symposium Proceedings: October 31November 4, 2005, Albany, New York, p. 40-47.

Lieberman, H.R., 2007, Hydration and cognition: A critical review and recommendations for future research: Journal of the American College of Nutrition, v. 26, supplement 5, p. 555S-561S.

Mattimore, V., and Battista, J.R., 1996, Radioresistance of Deinococcus radiodurans: Functions necessary to survive ionizing radiation are also necessary to survive desiccation: Journal of Bacteriology, v. 178, p. 633-637.

McCarty, G.W., and Bremmer, J.M., 1991, Production of urease by microbial activity in soils under aerobic and anaerobic conditions: Biology of Fertile Soils, v. 11, p. 228-230. doi:10.1007/BF00335772.

Miteva, V.I., and Brenchley, J.E., 2005, Detection and isolation of ultrasmall microorganisms from a 120,000-year-old Greenland glacier ice core: Applied and Environmental Microbiology, v. 71, p. 7806-7818. doi:10.1128/AEM.71.12.7806-7818.2005.

Mobley, H.L.T., and Hausinger, R.P., 1989, Microbial ureases: Significance, regulation, and molecular characterization: Microbiology Reviews, v. 53, p. $85-108$.

Northup, D.E., Barns, S.M., Yu, L.E., Spilde, M.N., Schelble, R.T., Dano, K.E., Crossey, L.J., Connolly, C.A., Boston, P.J., Natvig, D.O., and Dahm, C.N., 2003, Diverse microbial communities inhabiting ferromanganese deposits in Lechuguilla and Spider Caves: Environmental Microbiology, v. 5, p. 1071-1086. doi:10.1046/j.14622920.2003.00500.x.

Northup, D.E., Beck, K.M., and Mallory, L.M., 1997, Human impact on the microbial communities of Lechuguilla Cave: Is protection possible during active exploration? [abstract]: Journal of Cave and Karst Studies, v. 59, $166 \mathrm{p}$.

Pace, N.R., 1997, A molecular view of microbial diversity and the biosphere: Science, v. 276, p. 734-740. doi:10.1046/j.1462-2920. 2003.00500.x.

Palmer, A.N., and Palmer, M.V., 2000, Hydrochemical interpretation of cave patterns in the Guadalupe Mountains, New Mexico: Journal of Cave and Karst Studies, v. 62, p. 91-108.

Raesly, R.L., and Gates, J.E., 1987, Winter habitat selection by north temperate cave bats: American Midland Naturalist, v. 118, p. 15-31.

Rainey, F.A., Ray, K., Ferreira, M., Gatz, B.Z., Fernanda Nobre, M., Bagaley, D., Rash, B.A., Park, M.-J., Earl, A.M., Shank, N.C., Small, A.M., Henk, M.C., Battista, J.R., Kämpfer, P., and da Costa, M.S., 2005, Extensive diversity of ionizing-radiation-resistant bacteria recovered from Sonoran Desert soil and description of nine new species of the genus Deinococcus obtained from a single soil sample: Applied and Environmental Microbiology, v. 71, p. 5225-5235. doi:10.1128/AEM.71.9.5225-5235.2005.

Rappé, M.S., Connon, S.A., Vergin, K.L., and Giovannoni, S.J., 2002, Cultivation of the ubiquitous SAR11 marine bacterioplancton clade: Nature, v. 418, p. 630-633. doi:10.1038/nature00917.
Reames, S., Fish, L., Burger, P., and Kambesis, P., 1999, Deep Secrets: The Discovery and Exploration of Lechuguilla Cave: Dayton, Cave Books, $381 \mathrm{p}$.

Roman, M., Dovi, R., Yoder, R., Dias, F., and Warden, B., 1991, Determination by ion chromatography and spectrophotometry of the effects of preservation on nitrite and nitrate: Journal of Chromatography A, v. 546, p. 341-346. 10.1016/S0021-9673(01)93032-8.

Scholle, P.A., Ulmer, D.S., and Melim, L.A., 1992, Late-stage calcites in the Permian Capitan Formation and its equivalents, Delaware Basin margin, west Texas and New Mexico: evidence for replacement of precursor evaporites: Sedimentology, v. 39, p. 207-234. doi:10.1111/ j.1365-3091.1992.tb01035.x.

Sellin, M., Gillespie, W.A., Cooke, D.I., Sylvester, D.G.H., and Anderson, J.D., 1975, Micrococcal urinary-tract infections in young women: The Lancet, v. 2, p. 570-572. 10.1016/S0140-6736(75)90166-X.

Spear, J.R., Barton, H.A., Robertson, C.E., Francis, C.A., and Pace, N.R., 2007, Microbial community biofabrics in a geothermal mine adit: Applied and Environmental Microbiology, v. 73, p. 6172-6180. doi:10.1128/AEM.00393-07.

Stamatakis, A., Hoover, P., and Rougemont, J., 2008, A fast bootstrapping algorithm for the RAxML web-servers: Systematic Biology, v. 57, p. 758-771. doi:10.1080/10635150802429642.

Stone, W., am Ende, B., and Paulsen, M., 2002, Beyond the Deep: The Deadly Descent into the World's Most Treacherous Cave: New York, Time Warner Books, 351 p.

Summers Engel, A., Meisinger, D.B., Porter, M.L., Payn, R.A., Schmid, M., Stern, L.A., Schleifer, K.H., and Lee, N.M., 2010, Linking phylogenetic and functional diversity to nutrient spiraling in microbial mats from Lower Kane Cave (USA): The ISME Journal, v. 4, p. 98-110. doi:10.1038/ismej.2009.91.

Tabor, J.M., 2010, Blind Descent: The Quest to Discover the Deepest Place on Earth: New York, Random House, 286 p.

Walter, B., Hänssler, E., Kalinowski, J., and Burkovski, A., 2007, Nitrogen metabolism and nitrogen control in corynebacteria: Variations of a common theme: Journal of Molecular and Microbiology Biotechnology, v. 12, p. 131-138. doi:10.1159/000096468.

Wieser, M., Denner, E.B., Kämpfer, P., Schumann, P., Tindall, B., Steiner, U., Vybiral, D., Lubitz, W., Maszenan, A.M., Patel, B.K., Seviour, R.J., Radax, C., and Busse, H.J., 2002, Emended descriptions of the genus Micrococcus, Micrococcus luteus (Cohn 1872) and Micrococcus lylae (Kloos et al. 1974): International Journal of Systematic and Evolutionary Microbiology, v. 52, p. 629-637.

Wright, P.A., 1995, Nitrogen excretion: Three end products, many physiological roles: Journal of Experimental Biology, v. 198, p. 273-281.

Zhao Bin, He Yi Liang, and Zhang Xiao Fan, 2010, Nitrogen removal capability through simultaneous heterotrophic nitrification and aerobic denitrification by Bacillus sp. LY: Environmental Technology, v. 31, p. 409-416. doi:10.1080/09593330903508922. 